\title{
Arthrogryposis, hydranencephaly and cerebellar hypoplasia syndrome in neonatal calves resulting from intrauterine infection with Aino virus
}

\author{
Tomoyuki TsudA ${ }^{\mathrm{a} *}$, Kazuo YoshIDA ${ }^{\mathrm{b}}$, Seiichi OHASHI ${ }^{\mathrm{b}}$, Tohru YANASE $^{\mathrm{a}}$, \\ Masuo SUEYOSHI ${ }^{\mathrm{c}}$, Syunichi KAMIMURA ${ }^{\mathrm{d}}$, Kazuhiro MisUMI ${ }^{\mathrm{d}}$, \\ Katsumi HAMANA ${ }^{d}$, Hiroshi SAKAMOTO ${ }^{\mathrm{d}}$, Makoto YAMAKAWA ${ }^{\mathrm{a}}$ \\ ${ }^{a}$ Clinical Virology Section, Kyushu Research Station, National Institute of Animal Health, \\ 2702 Chuzan, Kagoshima 891-0105, Japan \\ b Exotic Disease Research Division, National Institute of Animal Health, 6-20-1 Jyosuihon-cho, \\ Kodaira, Tokyo 187-0022, Japan \\ ${ }^{c}$ Department of Veterinary Science, Faculty of Agriculture, Miyazaki University, \\ 1-1 Gakuen Kibana-dai Nishi, Miyazaki 889-2192, Japan \\ d Department of Veterinary Medicine, Faculty of Agriculture, Kagoshima University, \\ 1-21-24 Kohrimoto, Kagoshima 890-0065, Japan
}

(Received 4 December 2003; accepted 2 March 2004)

\begin{abstract}
To determine the teratogenic potential of Aino virus (AINOV) in cattle, pregnant cows and fetal cattle were infected with a fresh isolate of AINOV. Five pregnant cows were inoculated intravenously with the virus at 122 to 162 days of gestation and allowed to give birth. All of the cows developed neutralizing antibodies to the virus, indicating that the cows had been infected with the virus; however, no clinical abnormalities were seen in their six newborn calves, and no specific antibodies to the virus were detected in the precolostral serum of calves. Five fetuses with fetal ages ranging from 132 to 156 days were inoculated in utero with the virus. One weak newborn and four stillborn calves were delivered at gestation days 256 to 263, i.e., less than the standard gestation term; they had congenital abnormalities including arthrogryposis, hydranencephaly and cerebellar hypoplasia. Antibodies specific to AINOV were detected in their precolostral serum. These results demonstrate that AINOV is a potential etiological agent of congenital malformation of cattle.
\end{abstract}

\section{Aino virus / cattle / congenital malformation / experimental infection}

\section{INTRODUCTION}

Aino virus (AINOV) is an arthropodborne virus belonging to the Orthobunyavirus genus of the Bunyaviridae family. Viruses of genus Orthobunyavirus are widely distributed in temperate to tropical areas of the world, and some of them have been shown to induce symptomatic or asymptomatic ill- ness of animals [13, 14]. Akabane virus (AKAV), which belongs to the same genus as AINOV, has been demonstrated to cause congenital malformation characterized by arthrogryposis and hydranencephaly (AH) syndrome in cattle, goat and sheep in Japan, Australia and Israel $[2,3,8,10,11]$. Epidemics of congenital malformation have been observed in newborn calves in southern

\footnotetext{
* Corresponding author: tsudat@ affrc.go.jp
} 
districts of Japan every 3 to 5 years. Although AKAV was diagnosed as the causative virus in the majority of cases, serological data have implicated AINOV as an additional probable cause of recent epidemics of congenital malformation $[1,4,12]$. A few hundred suspected cases of AINOV infection were reported in Kyushu and Chugoku districts in 1995-1996 and 1998-1999. There was a statistically significant correlation between cows with affected calves and the AINOV antibody in these cows. The calves with congenital malformation possessed neutralizing antibodies to AINOV in their precolostral sera. The prevalence of AINOV infection in cattle was verified in the summers of 1995 and 1998 with the isolation of AINOV from sentinel cattle and with the seroconversion of cattle in that area.

The diagnosis of these diseases can rarely be accomplished on the basis of virus isolation and depends largely on histopathology and serology. In the case of fullterm offspring, diagnosis depends on the detection of neutralizing antibodies in precolostral serum from the offspring and in the serum from its dam [3, 14]. However, the precolostral serum is not always available for diagnosis, and pathological and histopathological features of calves infected with AINOV are unknown because there have been no reported studies of experimental infections of pregnant cows with AINOV.

The purpose of this study was to determine the teratogenic potential of AINOV in fetal cattle and the pathological features of affected calves in order to improve diagnostic measures.

\section{MATERIALS AND METHODS}

\subsection{Viruses}

The AINOV strain, KSB-3/P/95, was isolated from sentinel cattle in August 1995. The virus was isolated in baby hamster kidney (BHK) cell cultures at first pas- sage, and subjected to two passages in mouse brains by intracranial inoculation of 1 to 2 day old suckling mice. The brains of suckling mice were emulsified with Eagle minimal essential medium (MEM) to a concentration of $10 \%$ and centrifuged at $3000 \mathrm{rpm}$ for $10 \mathrm{~min}$. The supernatant was stored at $-80^{\circ} \mathrm{C}$ until use for the challenge experiment.

AINOV (JaNAr 28 strain) and AKAV (OBE-1 strain) were propagated in hamster lung (HmLu-1) cell cultures. The BHK and HmLu-1 cells were grown in MEM containing $0.295 \%$ tryptose phosphate broth and $10 \%$ heat-inactivated calf serum. Medium without serum was used to propagate the viruses.

\subsection{Pregnant cows and experimental inoculation}

Ten pregnant Japanese black cows were allotted to two groups. Group A comprised five cows that were negative for AINOV neutralizing antibody and confirmed as susceptible to the virus. The gestation ages for the fetuses in this group on the day of inoculation ranged between 122 and 162 days. Group B had five cows with five fetuses, with fetal ages ranging from 132 to 156 days. One of the five was sero-negative but four cows possessed a neutralizing antibody to AINOV prior to experimental inoculation.

The cows of group A were intravenously injected with $10^{7}$ TCID $_{50}$ of AINOV per head. In group B, the uterus was exposed surgically followed by ventrolateral incision under anesthesia. The fetus was intraperitoneally injected with $10^{7}$ TCID $_{50}$ of AINOV with pinpoint precision through the uterine wall under monitoring by an ultrasonic endoscope. All of the cows were raised in insect-protected facilities throughout the experiment. Serum samples were obtained from all cows prior to virus inoculation and at the time of parturition. Serum samples were taken from calves at birth before they suckled colostrum. The newborn or stillborn 
Table I. Results of calving in group A cows infected with Aino virus.

\begin{tabular}{cccccc}
\hline Cow & $\begin{array}{c}\text { Gestation ages (days) } \\
\text { at virus inoculation }\end{array}$ & $\begin{array}{c}\text { Duration of } \\
\text { gestation (days) }\end{array}$ & No. of neonate & $\begin{array}{c}\text { Body weight } \\
(\mathrm{kg})\end{array}$ & Gross lesion \\
\hline 1020 & 141 & 276 & 2 & 32.5 & normal \\
& & & & 22 & normal \\
1021 & 122 & 297 & 1 & 28.5 & normal \\
1022 & 162 & 280 & 1 & 21.5 & normal \\
1024 & 160 & 291 & 1 & 28.5 & normal \\
1025 & 122 & 290 & 1 & 25 & normal \\
\hline
\end{tabular}

calves in group B were examined for gross abnormalities by autopsy.

\subsection{Serum neutralization test}

The serum neutralization test was carried out by the micro-titer method using AKAV and AINOV. Fifty microliter aliquots of serial two-fold dilutions of serum, in duplicate rows, were mixed with an equal volume of culture medium containing 100 TCID $_{50}$ of virus in flat-bottomed microplates. After incubation for $1 \mathrm{~h}$ at $37{ }^{\circ} \mathrm{C}$, $0.1 \mathrm{~mL}$ of $\mathrm{HmLu}-1$ cell suspension in GIT medium (Wako Junyaku, Osaka, Japan) was added to the mixture, which was then incubated for seven days at $37{ }^{\circ} \mathrm{C}$ under a $5 \% \mathrm{CO}_{2}$ atmosphere in a humidity chamber. The antibody titer was expressed as the reciprocal of the highest serum dilution at which cytopathic effect was inhibited.

\section{RESULTS}

\subsection{Infection of pregnant cows with AINOV}

In group A, a total of five pregnant cows were intravenously inoculated with AINOV. Since the cows had been vaccinated for AKAV prior to fertilization, they had antibodies to AKAV but not to AINOV before inoculation. The gestation ages for fetuses on the day of inoculation ranged between 122 and 162 days. The cows showed no clinical signs after virus inoculation until parturition except for temporary pyrexia. All of the cows were delivered of single or twin normal calves between 276 to 297 days of pregnancy. The condition of calves at birth is summarized in Table I. All the newborn calves were healthy with normal body weights between 21.5 and $32.5 \mathrm{~kg}$.

The antibody responses of cows after the challenge inoculation are shown in Table II. A cow antibody specific to AINOV developed after infection, and its titer rose to between 32 and 128 . No change of antibody titers against AKAV was observed in the serum of cows at the end of experiment. No antibodies to AKAV or AINOV were detected in the precolostral sera of newborn calves.

\subsection{Intrauterine infection of fetuses with AINOV}

In group B, five fetuses with fetal ages ranging from 132 to 156 days were inoculated in utero with AINOV and examined for gross abnormalities at birth. Five pregnant cows used for the experiment showed no obvious clinical signs during the gestation period. However, the uterus of all the cows had polyhydramnios at calving. Fetal ages on the day of inoculation and birth, and body condition of newborn calves at birth are summarized in Table III. One live born and four stillborn calves were delivered at gestation days ranging from 246 to 263 . The body weight of calves was between 14 and $20 \mathrm{~kg}$ at birth. The live born calf showed weakness, astasia and a lack of sucking activity. The calves were euthanized and 
Table II. Antibody responses of cows and neonates after inoculation with Aino virus in group A.

\begin{tabular}{|c|c|c|c|c|c|c|}
\hline \multirow{3}{*}{ Cow } & \multirow{2}{*}{\multicolumn{2}{|c|}{$\frac{\text { Antibody titer before infection }}{\text { Cows }}$}} & \multicolumn{4}{|c|}{ Antibody titer at parturition } \\
\hline & & & \multicolumn{2}{|c|}{ Cows } & \multicolumn{2}{|c|}{ Calves } \\
\hline & AINOV & AKAV & AINOV & AKAV & AINOV & AKAV \\
\hline \multirow[t]{2}{*}{1020} & $<2$ & 8 & 128 & 8 & $<2$ & $<2$ \\
\hline & & & & & $<2$ & $<2$ \\
\hline 1021 & $<2$ & 16 & 64 & 32 & $<2$ & $<2$ \\
\hline 1022 & $<2$ & 16 & 64 & 16 & $<2$ & $<2$ \\
\hline 1024 & $<2$ & 8 & 64 & 8 & $<2$ & $<2$ \\
\hline 1025 & $<2$ & 4 & 32 & 2 & $<2$ & $<2$ \\
\hline
\end{tabular}

Table III. Results of calving in group B after intrauterine inoculation with Aino virus.

\begin{tabular}{ccccccc}
\hline Cow & $\begin{array}{c}\text { Gestation ages } \\
\text { at inoculation (days) }\end{array}$ & $\begin{array}{c}\text { Duration of } \\
\text { gestation (days) }\end{array}$ & $\begin{array}{c}\text { No. of } \\
\text { neonates }\end{array}$ & $\begin{array}{c}\text { Body weight } \\
(\mathrm{kg})\end{array}$ & Parturition & $\begin{array}{c}\text { Gross } \\
\text { lesion* }\end{array}$ \\
\hline 1017 & 153 & 246 & 1 & 17 & weakness & $\mathrm{H}$ \\
1023 & 156 & 247 & 1 & 20 & stillbirth & $\mathrm{A} / \mathrm{H}$ \\
1026 & 132 & 263 & 1 & 14 & stillbirth & $\mathrm{A} / \mathrm{H} / \mathrm{CH}$ \\
1029 & 152 & 249 & 1 & 15 & stillbirth & $\mathrm{H}$ \\
1030 & 138 & 261 & 1 & 18 & stillbirth & $\mathrm{A} / \mathrm{H} / \mathrm{CH}$ \\
\hline
\end{tabular}

* A: arthrogryposis; $\mathrm{H}$ : hydranencephaly; $\mathrm{CH}$ : cerebellar hypoplasia.

examined for developmental abnormalities. All five calves were affected with hydranencephaly (H; Tab. III and Fig. 1) and three had arthrogryposis (A; Tab. III and Fig. 2). Cerebellar hypoplasia (CH; Tab. III and Fig. 1) was observed in two calves that had arthrogryposis and hydranencephaly. In hydranencephalic calves the cerebral cortex was represented by a thin shell of edematous brain tissue, filled with fluid in the cystically dilated lateral ventricles. Arthrogrypotic calves showed scoliosis and restriction of movement of limb joints.

Antibody titers of serum from cows and precolostral serum of calves are shown in Table IV. Four dams of fetuses possessed antibodies to AINOV before intrauterine inoculation of fetuses with AINOV and one dam was sero-negative for the neutralizing antibody to the virus at that time. The antibody titer of dams to AINOV largely or slightly increased after fetal inoculation.
High titers of neutralizing antibodies to AINOV were detected in the precolostral serum of all the calves at birth. The antibody titers of cows to AKAV were unaffected by the fetal inoculation, and these antibodies were not detected in precolostral serum of any of the calves.

\section{DISCUSSION}

In this study, the teratogenic potential of AINOV in cattle, a natural vertebrate host, was documented. The fact that specific antibodies to AINOV have been demonstrated in cattle, sheep, goat and wild ruminants indicate these animals are susceptible to the virus $[13,14]$. Although serologic data suggested that AINOV caused congenital abnormalities of cattle and sheep in Japan and Australia [1, 12], the pathogenicity of AINOV in cattle has not been demonstrated. Viral 


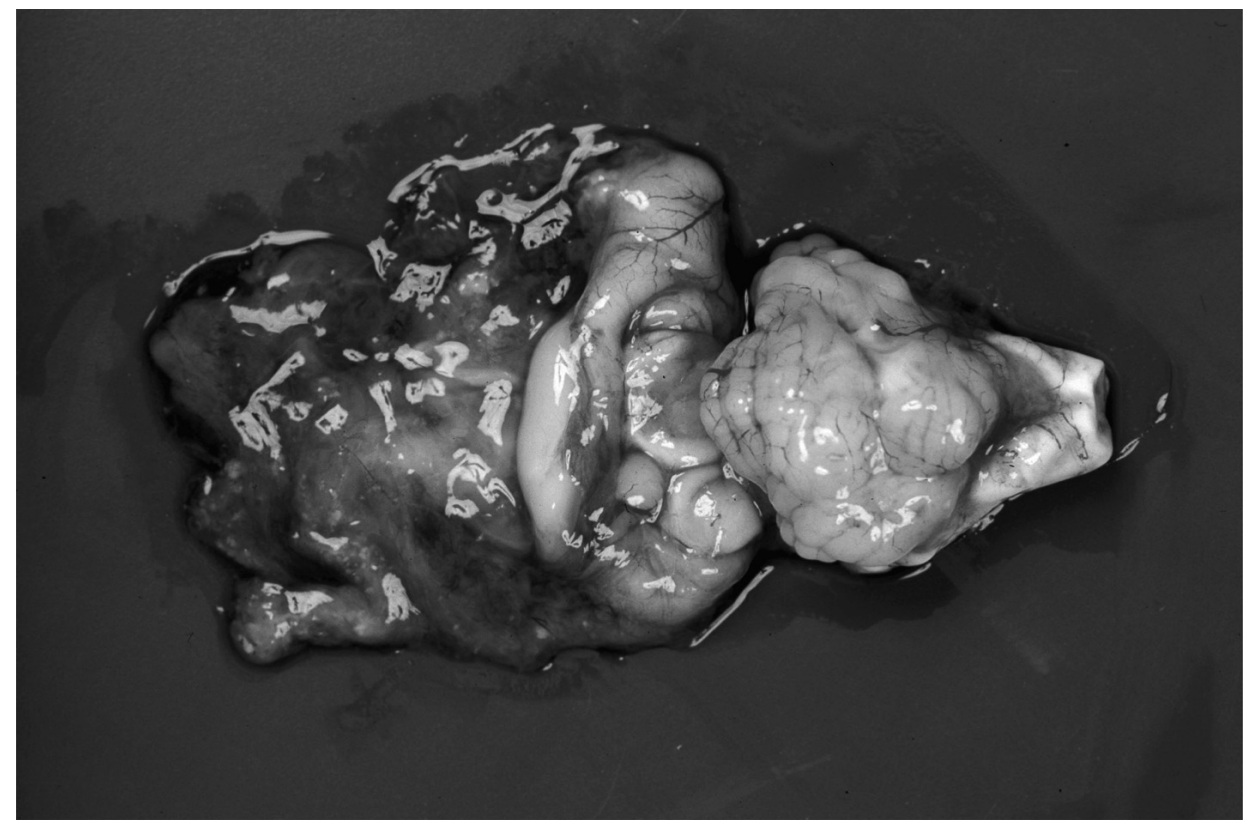

Figure 1. Macroscopic finding of hydranencephaly and cerebellar hypoplasia in a calf (No. 1030) infected in utero with Aino virus.

teratogenicity in cattle and sheep has been well demonstrated for AKAV [2, 8, 11, 13], a member of bunyavirus; however, the teratogenicity of AINOV has been examined only in chick embryos [5-7]. To determine the role of AINOV in inducing congenital malformation, fetal cattle were exposed to maternal and direct routes of infection with the virus and examined for transplacental activity of the virus and developmental abnormalities. The fresh isolate of AINOV used in this study possessed similar antigenicity to the prototype strain of AINOV [15]; however, the isolate was propagated in suckling mice before experimental inoculation to minimize its pathogenic alteration. In an epidemic of congenital malformation of cattle in 1995-1996 in Japan, the birth of affected calves was concentrated in the winter period from December through March, while the isolation of AINOV from sentinel cattle was concentrated in the summer period from July through August 1995. This evidence suggests that the fetus had been infected with the virus mainly from 120 to 180 days of gestation. The challenge inoculation with virus was conducted on the day of supposed gestation ages for the fetus.

The cows infected with AINOV delivered normal calves after a normal term pregnancy. The neutralization test of precolostral serum of calves revealed that the calves were not infected with the virus in the uterus. In the case of AKAV infection, data on precolostral sera from newborn calves and sera from their mothers in the epidemic areas has suggested that the virus invades the fetus in about $33 \%$ of infected pregnant cows [3]. All the calves from five pregnant cows infected with AINOV were free from fetal infection with virus. These results suggest that the rate of transplacental infection of AINOV may be lower than that of AKAV, resulting in the lower incidence of disease caused by AINOV than by AKAV in the field. 


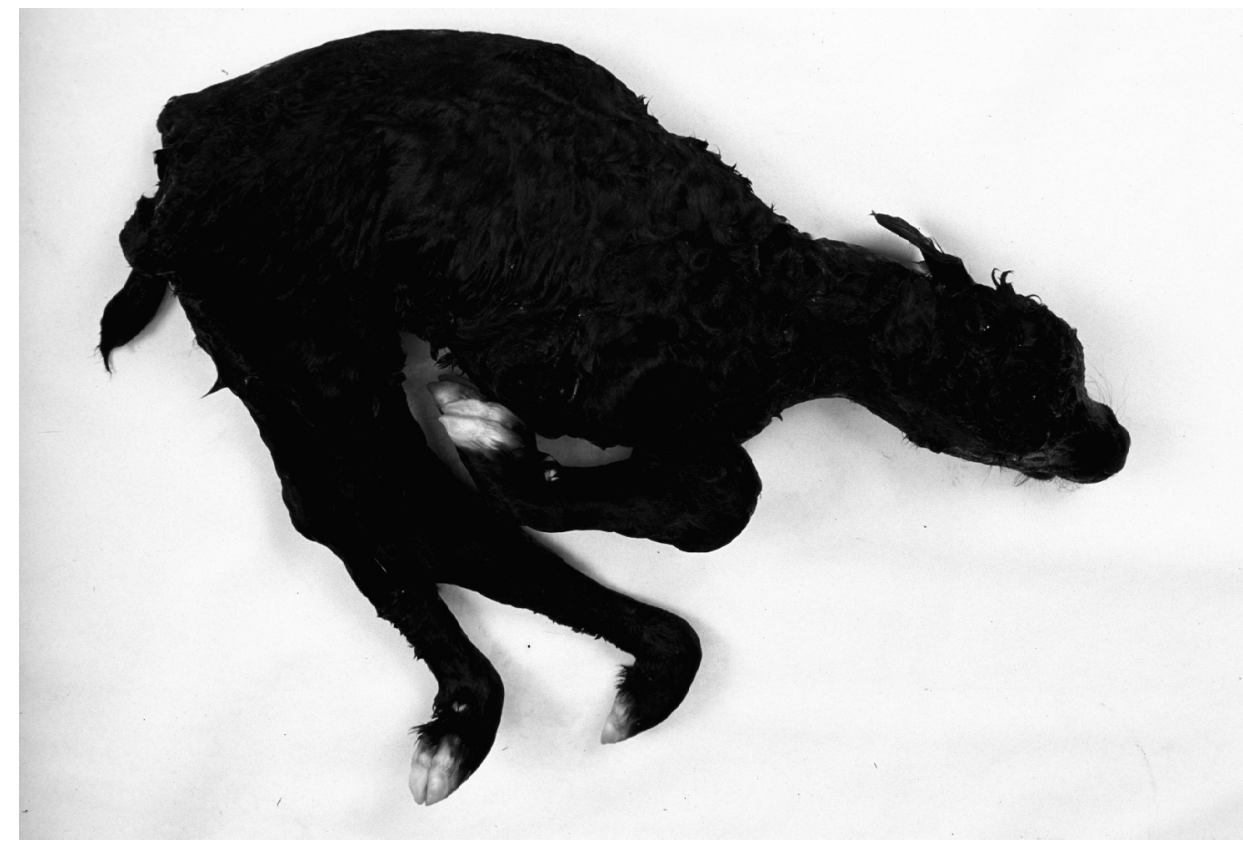

Figure 2. This calf (No. 1030) had arthrogryposis. The calf showed scoliosis and its limbs locked in flexion.

Table IV. Antibody responses of cows and neonates in group B before intrauterine inoculation with Aino virus and at birth.

\begin{tabular}{|c|c|c|c|c|c|c|}
\hline \multirow{3}{*}{ Cow } & \multirow{2}{*}{\multicolumn{2}{|c|}{$\begin{array}{c}\text { Antibody titer before infection } \\
\text { Cows }\end{array}$}} & \multicolumn{4}{|c|}{ Antibody titer at parturition } \\
\hline & & & \multicolumn{2}{|c|}{ Cows } & \multicolumn{2}{|c|}{ Precolostral serum of calves } \\
\hline & AINOV & AKAV & AINOV & AKAV & AINOV & AKAV \\
\hline 1017 & $<2$ & 16 & 16 & 8 & 256 & $<2$ \\
\hline 1023 & 16 & 16 & 32 & 16 & 64 & $<2$ \\
\hline 1026 & 8 & 16 & 64 & 8 & 16 & $<2$ \\
\hline 1029 & 32 & 16 & 256 & 16 & 256 & $<2$ \\
\hline 1030 & 32 & 4 & 64 & 8 & 32 & $<2$ \\
\hline
\end{tabular}

The intrauterine inoculation of fetuses with AINOV caused congenital malformation of calves from all five pregnant cows. The term of pregnancy of these cows was between 246 and 263 days, which was shorter by about 20 to 30 days than the average full-term gestation period of Japanese black cows (285 days) and that of cows in group A in this experiment. Premature birth and stillbirth were observed in the 19951996 and 1998-1999 Japanese epidemics of congenital malformation of calves, some of whom were suspected of AINOV infection. The body weight of group B calves was lighter than normal calves in group A. The data of fetal age of newborn calves and 
body weight, together with pathological findings, suggested that these calves died just before their delivery. The mortality of the fetus in the latter stage of gestation should be examined further.

All the calves in group B had congenital malformation, characterized by hydranencephaly, arthrogryposis and cerebellar hypoplasia. It has been demonstrated that hydranencephaly and arthrogryposis of calves are typical congenital malformations in cases of intrauterine infection of AKAV [2, 3, 8]. The results of this study revealed that AINOV was equally teratogenic for cattle as AKAV. It has been shown that chick embryos manifest marked hydranencephaly, cerebellar hypoplasia, arthrogryposis and scoliosis by inoculation into the yolk sac of eight days embryo with AINOV [57]. Kitano et al. [6] mentioned that cerebellar hypoplasia in AINOV-infected chick embryos constitutes a distinctive difference from AKAV-infected chick embryos, which showed hydranencephaly and myopathy [9]. In this study cerebellar hypoplasia was observed in 2 out of the 5 affected calves. Since such findings were not observed in AKAV-infected calves [8, 11], cerebellar hypoplasia seems to be a characteristic of pathological changes caused by AINOV infection. Arthrogrypotic calves showed scoliosis and restriction of movement of limb joints. Scoliosis in arthrogrypotic calves was a noticeable finding in cases of the 19951996 epidemic attributed to AINOV infection; this finding also seemed to be specific to AINOV-affected calves.

Developmental malformation was induced by inoculation with AINOV at gestation ages between 132 and 156 days. Similar congenital abnormalities in newborn calves were experimentally induced by inoculation of pregnant cows with AKAV at 92 to 96 days of gestation [11]. The primary pathological lesions in fetuses infected with AKAV were encephalomyelitis and polymyositis [8]. Of fetuses surviving the infection, some gradually developed brain lesions such as hydranencephaly, spongiform lesions and marked reduction in the number of motor neurons in the spinal anterior horn [3]. This pathogenesis of AKAV was considered to be the same as AINOV. The results in this study suggested that, for AINOV, the critical gestational stage when infection occurred and resulted in congenital malformation was between 132 and 156 days.

As expected, the presence of maternal AINOV-specific antibody before fetal inoculation did not protect the fetus from viral infection, and all fetuses of these dams had clinical abnormalities after intrauterine inoculation with AINOV. Although the dams were not infected directly with the virus, their neutralizing antibodies rose after intrauterine infection of their fetuses. This specific antibody of dams was probably elicited by virus from affected fetus. This fact suggested that the transplacental transmission of virus from fetus to dam might occur in pregnant cows whose fetuses were affected with AINOV.

In conclusion, AINOV is a potential teratogenic pathogen in cattle and the lesions produced by intrafetal inoculation with AINOV are consistent with those reported from field cases where AINOV has been serologically implicated.

\section{ACKNOWLEDGEMENTS}

This research was implemented under the approval No. 102 of Committee for Animal Welfare, National Institute of Animal Health. We thank the National Livestock Breeding Center and Kagoshima Prefectural Cattle Breeding Development Institute for providing experimental animals. This research was supported by grants received from the Ministry of Agriculture, Forestry and Fisheries of Japan.

\section{REFERENCES}

[1] Coverdale O.R., Cybinski D.H., St.George T.D., Congenital abnormalities in calves associated with Akabane virus and Aino virus, Aust. Vet. J. 54 (1978) 151-152. 
[2] Inaba Y., Kurogi H., Omori T., Akabane disease: epizootic abortion, premature birth and congenital arthrogryposis-hydranencephaly in cattle, sheep and goats caused by Akabane virus, Aust. Vet. J. 51 (1975) 584-585.

[3] Inaba Y., Matsumato M., Akabane virus, in: Dinter Z., Morein B. (Eds.), Virus infections of ruminants, Elsevier Science Publishers, Amsterdam, 1990, pp. 467-480.

[4] Ishibashi K., Tomishita Y., Shirakawa H., Takaya M., Watanabe A., Congenital scoliosis of calves suspected of Aino virus infection, Jpn. J. Vet. Med. Assoc. 47 (1994) 87-90 (in Japanese with English summary).

[5] Kitano Y., Ohzono H., Shimizu T., Proliferation and teratogenicity of Aino virus in chick embryos, Microbiol. Immunol. 40 (1996) 85-88.

[6] Kitano Y., Ohzono H., Yoshida N., Shimizu T., Hydranencephaly, cerebellar hypoplasia, and myopathy in chick embryos infected with Aino virus, Vet. Pathol. 33 (1996) 672-681.

[7] Kitano Y., Yoshida N., Shimizu T., Ohzono H., Iwamoto T., Teratogenicity of Aino virus in the chick embryo, Res. Vet. Sci. 62 (1997) 195-198.

[8] Konno S., Nakagawa M., Akabane disease in cattle: congenital abnormalities caused by viral infection. Experimental disease, Vet. Pathol. 19 (1982) 267-279.

[9] Konno S., Koeda T., Madarame H., Ikeda S., Sasaki T., Satoh H., Nakano K., Myopathy and encephalopathy in chick embryos experimentally infected with Akabane virus, Vet. Pathol. 25 (1988) 1-8.
[10] Kurogi H., Inaba Y., Takahashi E., Sato K., Omori T., Miura Y., Goto Y., Fujiwara Y., Hatano Y., Kodama K., Fukuyama S., Sasaki N., Matumoto M., Epizootic congenital arthrogryposis-hydranencephaly syndrome in cattle: isolation of Akabane virus from affected fetuses, Arch. Virol. 51 (1976) 67-74.

[11] Kurogi H., Inaba Y., Takahashi E., Sato K., Satoda K., Goto Y., Omori T., Matumoto M., Congenital abnormalities in newborn calves after inoculation of pregnant cows with Akabane virus, Infect. Immun. 17 (1977) 338343.

[12] Miura Y., Hayashi S., Ishihara T., Inaba Y., Omori T., Matumoto M., Neutralizing antibody against Akabane virus in precolostral sera from calves with congenital arthrogryposis-hydranencephaly syndrome, Arch. Gesamte Virusforsch. 46 (1974) 377-380.

[13] Parsonson I.M., McPhee D.A., Bunyavirus pathogenesis, in: Maramorosch K., Murphy F.A., Shatkin A.J. (Eds.), Advances in virus research, Vol. 30, Academic Press, Orlando, 1985, pp. 279-316.

[14] Porterfield J.S., Della-Porta A.J., Bunyaviridae: infections and diagnosis, in: Kurstak E., Kurstak C. (Eds.), Comparative diagnosis of viral diseases, Vol. IV, Academic Press, New York, 1981, pp. 479-508.

[15] Yoshida K., Ohashi S., Kubo T., Tsuda T., Comparison of intertypic antigenicity of Aino virus isolates by dot immunobinding assay using neutralizing monoclonal antibodies, J. Clin. Microbiol. 38 (2000) 4211-4214. 